\title{
URBAN DESIGN FOR TSUNAMI IMPACT MITIGATION; APPLICATION OF PHYSICAL ELEMENT
}

\author{
Fahmyddin A'raaf Tauhid*1 \\ Department of Architecture, UIN Alauddin Makassar, Indonesia ${ }^{1}$ \\ e-mail: *1xfahmyddin.tauhid@uin-alauddin.ac.id
}

\begin{abstract}
The increasing of tsunami event has called the integration of urban design for disaster impact mitigation. The Geodynamics position of many global cities puts latter areas are highly vulnerable to earthquake followed by tsunamis. In supporting its function as the main hub in social and economic and protecting environment, the employment of urban design for tsunami impact mitigation is hypothesized as sustainable mean. Therefore, this paper seeks the possibility of employment of urban design's physical element for tsunami impact mitigation within disaster studies field using literature and case studies for Indonesian cities context. This study recommends that Infrastructure planning and design, Coastal forest, Early warning system, Emergency road network planning, Pre-tsunami evacuation planning and Building design and construction are suitable physical element for impact mitigation.
\end{abstract}

Keywords: Urban Design; Tsunami; Mitigation; Physical Element.

${ }^{1}$ Department of Architecture, Faculty of Science and Technology UIN Alauddin Makassar, Indonesia 


\section{INTRODUCTION}

The current world's agenda has called for theintegration of urban design for disaster mitigation efforts. The Geodynamics position of many cities around the world puts them are vulnerable to earthquake followed by tsunamis (Løvholt et al. 2011). Recent occurrences of major earthquakes and tsunamis, such as the Indian Ocean tsunami in 2004 and the Japan tsunami in 2011 and 2018 Sulawesi tsunami in Palu city, Indonesia have challenged the resilience of the affected cities. To prevent these cities for enabling their function as the main hub in social and economic and protecting environment, the employment of urban design element is viewed as applicable mean (Lunecke 2015; Chmutina et al,2013;Santibáñez2016).

The increasing of tsunami globally has caused massive damage to infrastructure and properties in coastal urban area while also caused enormous loss of life (Løvholt et al., 2011). Mitigation is often considered as the sustainable way to deal with these problems (Lunecke 2015). However, its accepted definitions and forms have been argued by some studies. FEMA (2015) defines mitigation as the effort to reduce loss of life and property by lessening the impact of disasters. Geis (2000) describes it as a process for disaster risk reduction, charged with planning and building the various systems and components of the built environment to minimize loss of life, damage to property from the actual event and the subsequent socio-economic disruption. Haque (2005) contend that mitigation can be defined as foundation of disaster management.

The employment of urban design element as mitigation measures have been discussed as of effective method particularly in tsunami vulnerable waterfront areas. Chmutina et al, (2013) conclude integration of disaster reduction into urban design effort by urban stakeholder would be a key disaster in impact mitigation effort. Santibáñez (2016) also argues that urban design might be incorporate in planning coastal cities to improve resilience to earthquakes and tsunamis and to meet minimum standards for ensuring that the inhabitants would be safer and better prepared for evacuation. NTHMP (2001) recommended some urban design element standard to reduce and mitigate the tsunami impacts in vulnerable cities particularly in USA. Yet, the application of urban design element to reduce the tsunami impact have a little discussion within the field of urban design and disaster management. Therefore, this paper seeks the employment of such urban design physical element for impact mitigation within disaster studies field using literature and case studies.

\section{URBAN DESIGN ELEMENT FOR TSUNAMI IMPACT MITIGATION}

When the risk is a tsunami, due to its character; low frequency, high consequences, dealing with mitigation means making trade off among competing goals (NTHMP 2001). Its mitigation application may have high physical impact for the affected community, hence it is essential adjusting mitigation strategies with broader community goals, balancing uses of daily life with emergency function (Eisner 2005). It should be noted that no tsunami mitigation tools are responsive to all community and not all such mitigation measures are complete sustainable (Alesch 2012). Therefore, it is essential evaluating each community specific requirements living in tsunami prone area to improve decision making that adopt measures for structural and non-structural with long-term results (Mileti 1999).

Many cities are located in the tsunami prone areas (Løvholt et al. 2011). If tsunami occurs, these vulnerable cities will experience the massive damages and losses due to concentration of people, buildings, infrastructure and socio-economic activities (fig. 1) (Papathoma 2003, Pelling 2003). 


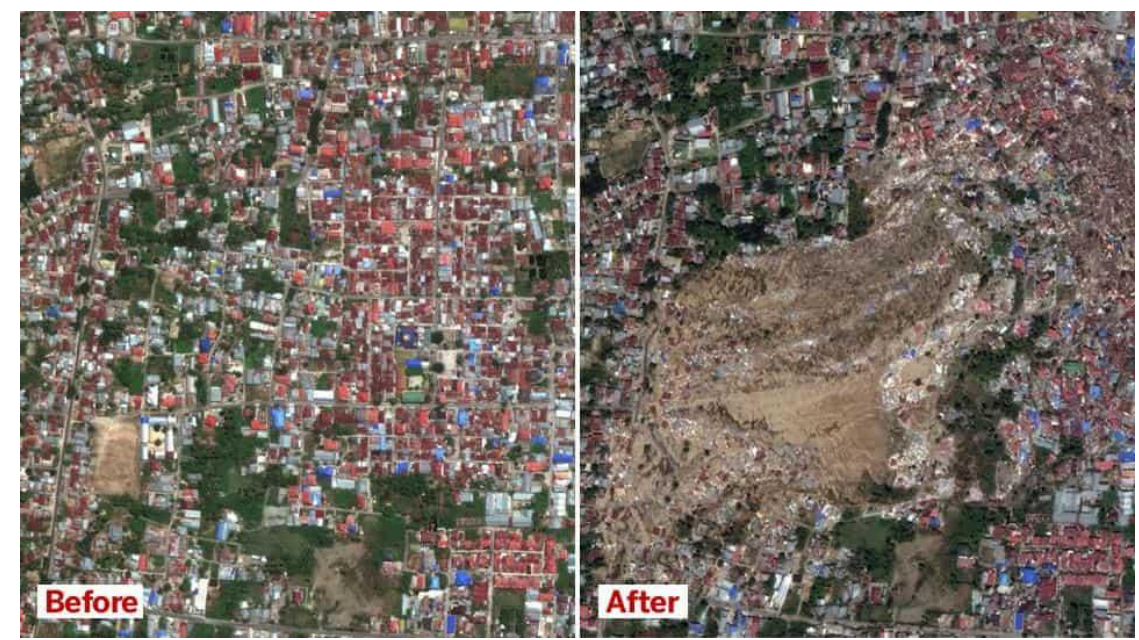

Figure 1. Satellite Photo Of The Destruction In Palu City, Indonesia, On August 17, 2018, Prior To An Earthquake (Left) and On October 1, 2018, After An Earthquake and Subsequent Tsunami

(Source: Reuters Photo 2018)

Yet, there is no single method to use to mitigate the impact due to local character of environment, social, and economic condition (Farreras et al. 1991). Therefore, adopted mitigation will depend on local government and urban stakeholders to suit their conditions and needs. According to some studies, six urban design elements strategies can be implemented for structural mitigation plan; Infrastructure planning and design, Coastal forest, Early warning system, Emergency road network planning, Pre-tsunami evacuation planning and Building design and construction (NTHMP 2001, Budiarjo 2006, JICA 2005, Chatenoux et. al. 2007, BAPPENAS 2005, Morrissey 2005).

Infrastructure planning and design aim to integrate the public service and physical structure in the city to deal with tsunami impact. Such planning incorporates comprehensively the coastal structure; public emergency infrastructure; housing strategies; and vital infrastructure and critical facilities. The Coastal structures is designed to decrease destructive effect of the tsunami waves by considering local condition of geography, topography, and financial resources (ICE 1992). The types of structuresin the coastal line comprises detached breakwater and sea wall. Detached breakwaters protect the adjacent coastal line by minimizing incoming wave energy generated by storm surge, mid and small-scale tsunami (Mikami 2015) (fig 2). While, a sea wall structure is developed to protect infrastructure and settlement behind and reduce coastal line erosion. The data of Mikami (2015) also confirms the function of coastal structure in reducing the devastating impact of tsunami.

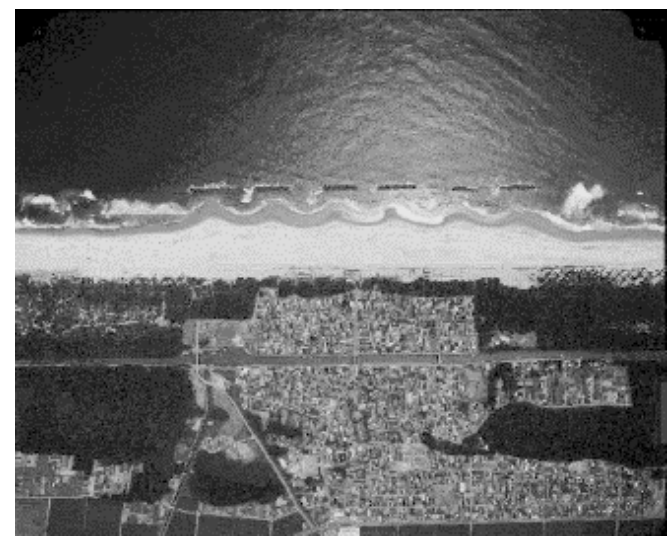

Figure 2. Detached Breakwater in Sendai Coast, Japan (Source: Tohoku univ. 2008) 
Development of public emergency infrastructure is critical point in mitigation planning as an escape destination point during tsunami. JICA (2005) and Budiarjo (2006) recommended the components of public emergency infrastructure associated with urban design physical element for tsunami impact mitigation comprises Escape building, Escape bridge, Emergency base and City Park. After tsunami struck, early warning system is issued to vulnerable inhabitants for an evacuation time. In such limited time, escape buildings or evacuation shelter buildings can operate as temporary shelters for those failing to reach higher ground or safer areas. These buildings must be developed along escape roads and might be reachable by walking or running. For escape bridges, they are built along the relief road network with its structure raised above the tsunami inundation level (fig. 3). Mostly, emergency base is stationed in open space such as a central park or a building functioned as escape destination point; rescue main base; and relief and temporary housing.

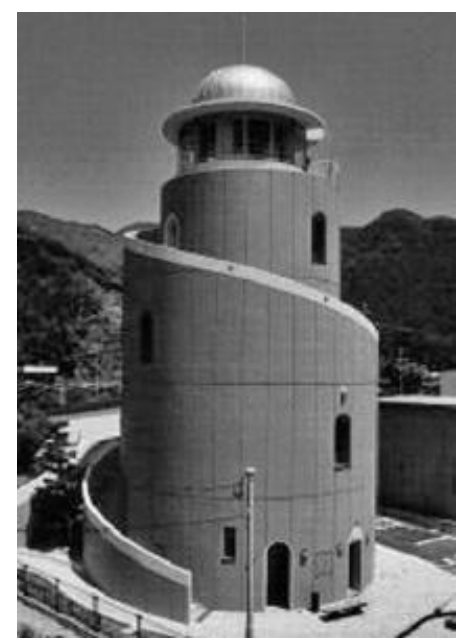

Figure 3. Typical Escape Building in Japan

(Source: Sendai city 2018)

Tsunami mitigation techniques for housing and settlement might be incorporated in structural mitigation plan since these are a concentration of inhabitants due to land scarcity. Some techniques that can be applied including high-density housing, Clustered buildings and tower building, building blocks orientation and arrangement, and functional arrangement in the building (Budiarjo 2006; JICA 2005)(fig 4). Communities are encouraged to live closer in high-rise housings or apartments to make the communication and coordination easier for evacuation.

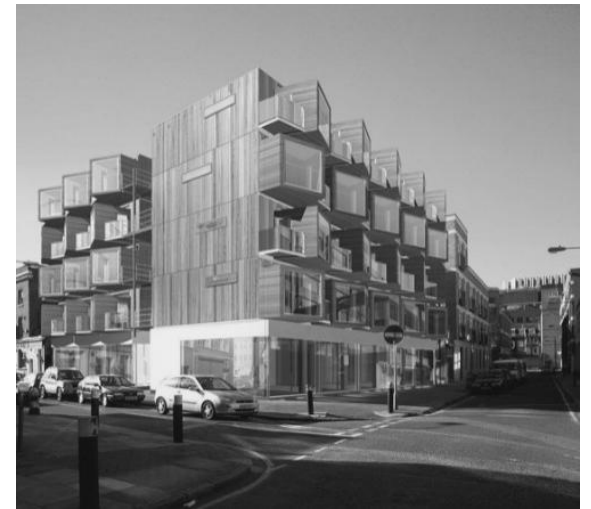

Figure 4. High Density Housing

(Source: Contemporist 2007) 
It is important to notethat vital infrastructure is rapidly repaired after a disaster occurred. According to NTHMP (2001), vital infrastructure encompasses the transportation systems and public utilities (fig 5). It must be maintained or repaired to reduce more damage and loses to support emergency response to inhabitants after tsunami struck. For instance, the postpone of road reconstruction in Aceh caused by Tsunami 2004 increased the poverty rate (World Bank, Badan Rehabilitasi dan Rekonstruksi Aceh, Aceh Province government 2008). Critical facilities are also important in a tsunami structural mitigation plan since they function to serve community. These facilities can be classified into three categories; essential services, special occupancy structures and hazardous facilities (NTHMP 2001).

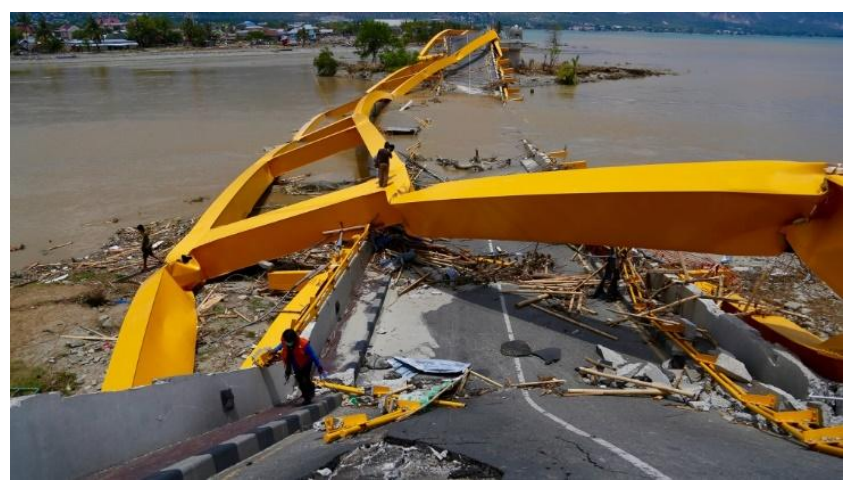

Figure 5. Destroyed Bridge in Palu After September 2018 Tsunami Isolated Palu City From Aid (Source: Aljazeera 2018)

Many recent studies show that Coastal forest can effectively decrease the tsunami wave energy (Chatenoux et. al. 2007, Chang et al. 2006, Alongi 2008). It can be a natural solution than artificial structures such as detached breakwater and seawall that may affect coastal environment. The secure the success of coastal forest for tsunami mitigation, some factors need to be considered including the width of forest, slope of the forest, tree density and height, presence of forest shore habitats (seagrass meadows, coral reef, dunes), distance from tectonic plate, size and speed of tsunami (estimate) and angle of tsunami incursion relative to the coastline (Barbier 2008; Aksornkaoe et. al. 1993; Brinkman et. al.1997). Study carried out by Chatenoux et. al. (2007) demonstrates that during the tsunami 2004, mangrove forest could reduce destructive waves without showing any apparent damage and protected housing and infrastructure behind(fig 6). An example of implementation of coastal forest program for tsunami impact mitigation can be seen in the figure 7.
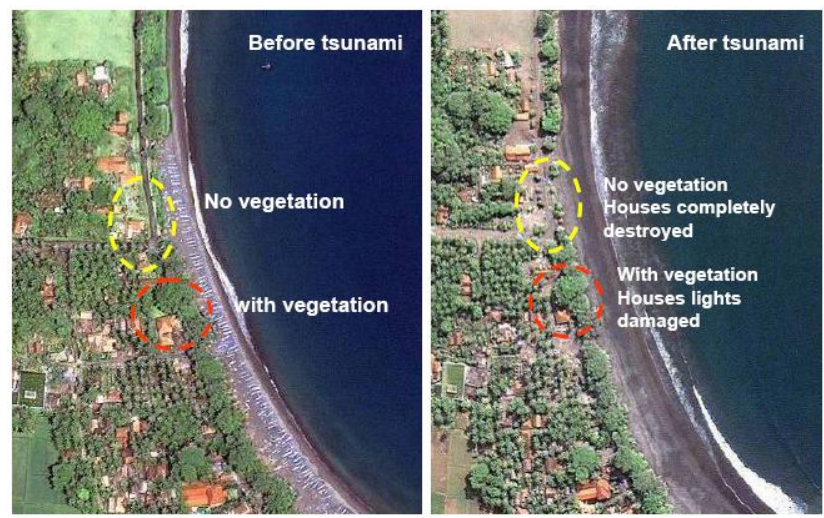

Figure 6: Ikonos imageries of Pre And Post The 2006 West Java Tsunami Shows The Role Of Coastal Forest To Reduce Tsunami At The Pangandaran Beach, Indonesia

(Source: CRPS 2006) 


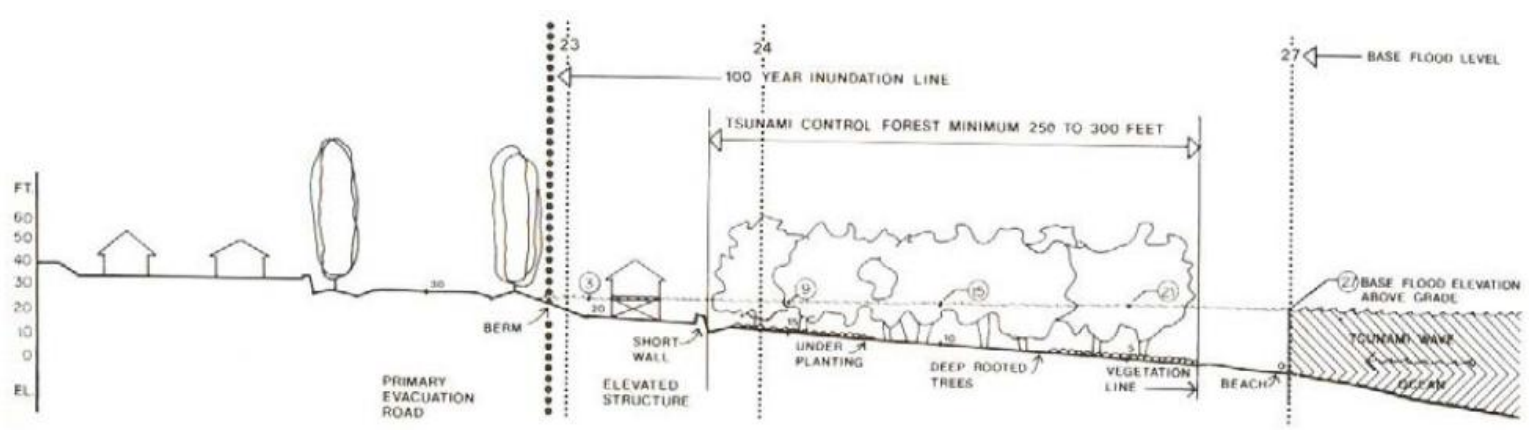

Figure 7. Siteplan Concept of Techniques in Avoiding, Slowing, Steering, and Blocking Tsunami Waves by The Tsunami Control Forest

(Source: Preuss)

In the aftermath of the Indian Ocean Tsunami 2004, the government and other stakeholders have identified how important the implementation of Early warning system to warn vulnerable people to evacuate before the tsunami reaching the coastal areas (Zschau 2003). An early warning system requires the tsunami travel time and evacuation time understanding (Budiarjo 2006). The tsunami travel time is defined as the available time for evacuation of people in coastal area (Budiarjo 2006). After an earthquake in open sea, the tsunami warning system require several minutes to calculate and decide whether it will cause a tsunami or not and if it does, the system also demands several minutes to alarm coastal people to evacuate. Therefore, the evacuation time can be defined as the remaining time to evacuate those to a safer place or higher ground before tsunami waves reaching coastal areas.

As the part of urban design element for tsunami mitigation, providing emergency roads to support the mobility of evacuation and aids is critical. Emergency roads comprise escape roads and relief roads (JICA 2005) (fig 8). Escape roads function to accommodate evacuee to escape from tsunami in a short time as possible. While Relief roads serve treatment effort; aid of first responder, evacuation, and the supply of relief materials. The emergency road network must be connected well with safer areas in surrounding tsunami-prone region. In addition, escape buildings or vertical escape and signage are developed along the escape road for those who failed to evacuate in time (JICA 2005, MCDEM 2008). 


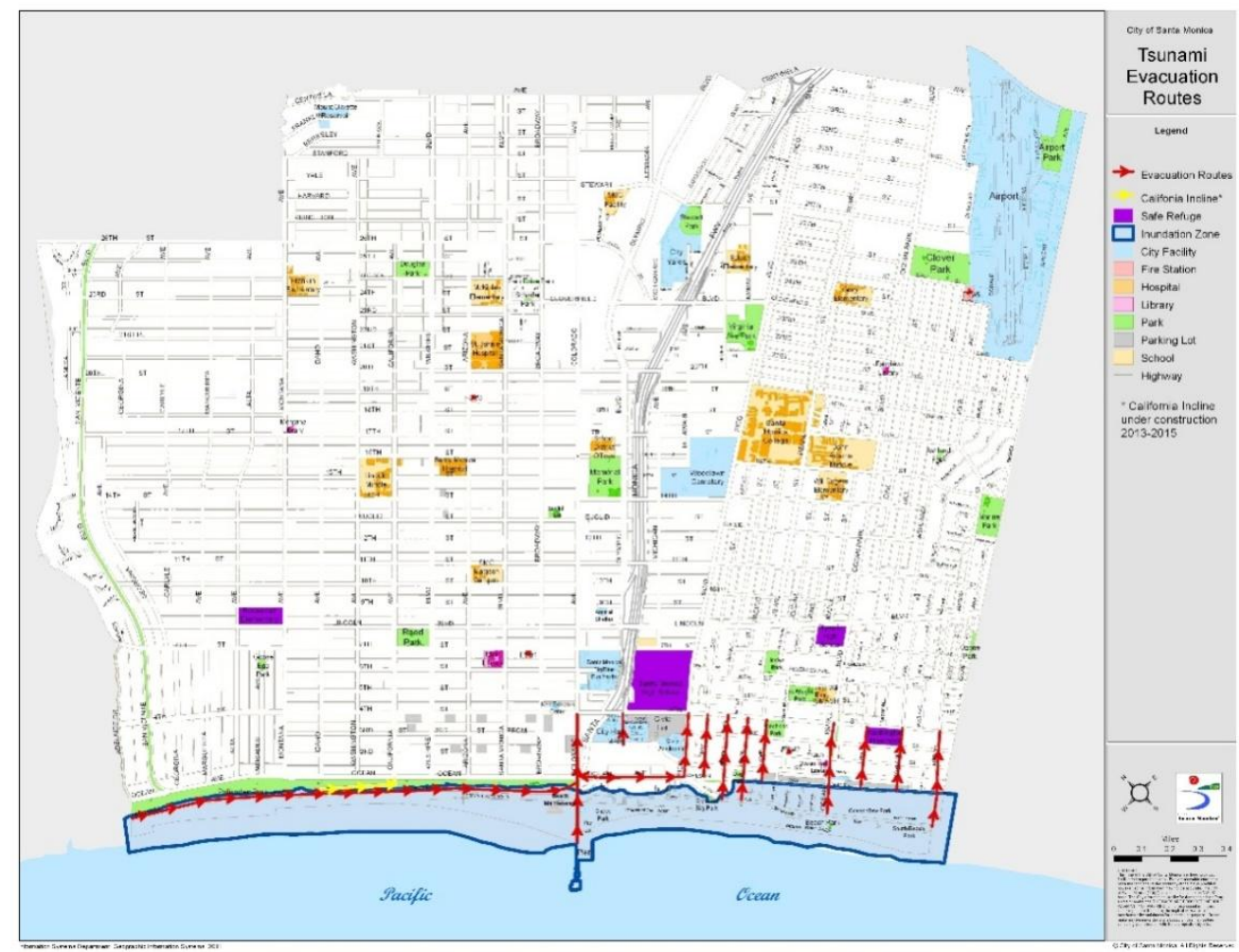

Figure 8. Intergration Emergency Road Plan and Evacuation in City of Santa Monica USA (Source: City of Santa Monica 2018)

To evacuate people in limited time from the hazard areas to the safer places is the main strategy before tsunami waves arrive to reduce the loss of life. The method of evacuation comprises two models; Horizontal evacuation and Vertical evacuation (NTHMP 2001)(fig.9). Horizontal evacuation evacuates people from the hazard areas to the safer places in a distant areas or higher ground. Horizontal evacuation is mostly used in many tsunami prone-areas. In vertical evacuation method, tsunami threatened people are evacuated to the upper floors of the sturdy multi-floors buildings located around them. Horizontal and Vertical evacuation methods may be applied solely or together in the pre-tsunami evacuation development (fig.10). The implementation of these methods needs estimating the available evacuation time, land topography, infrastructure and facilities as well as wave run-up speed and inundation level (Shibayama et al. 2013). Commonly, cities located in coastal areas has insufficient and infrastructure for horizontal. Dealing with these problems, vertical evacuation is considered as an alternative method (NTHMP 2001). Other issues such as land use planning, site planning as well as building design must be also involved in the development of vertical evacuation facilities to ensure effective evacuation planning (Shibayama et al. 2013). The failure to plan and design of evacuation method may lead to a great loss and destruction, for instance, the research by Shibayama et al. (2013) on the Great Eastern Japan Earthquake and Tsunami of 2011 found that some of the designated Evacuation Buildings were below the tsunami inundation level. 


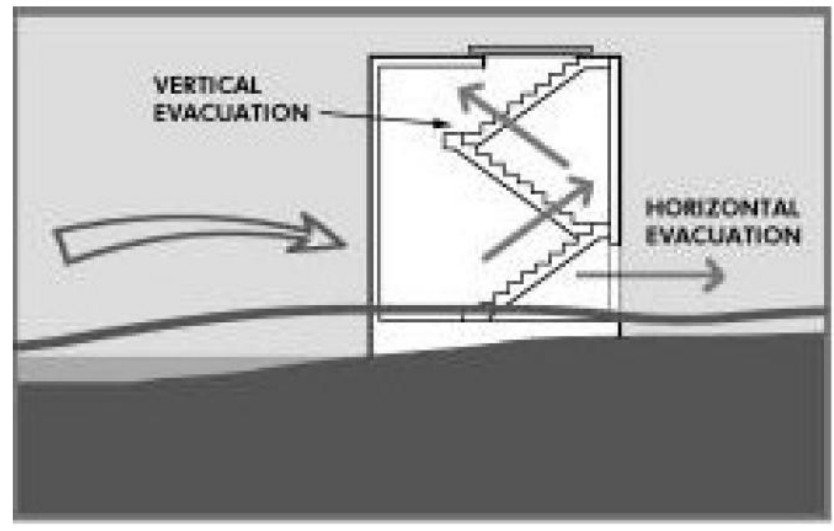

Figure 9. Vertical and Horizontal Evacuation (Source: NTHMP 2001)

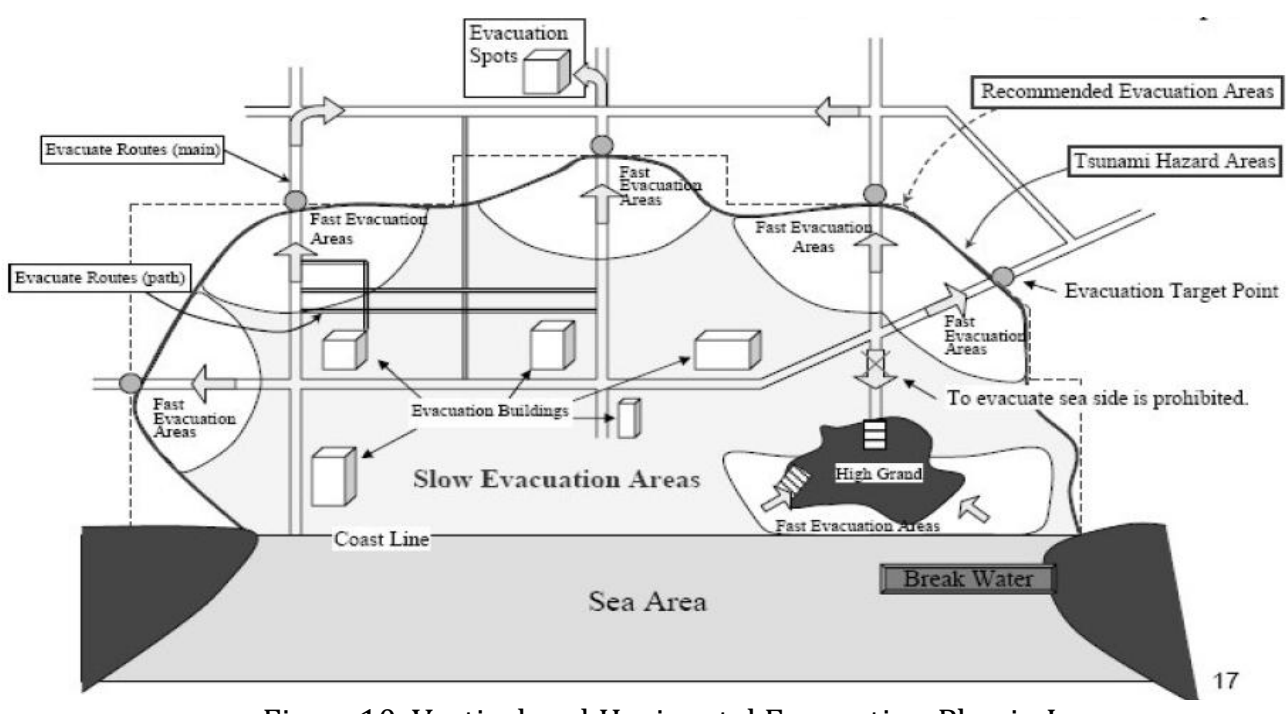

Figure10. Vertical and Horizontal Evacuation Plan in Japan Source: Nagao, 2005

During tsunami striking, it is highly recommended that building and construction could reduce loss of life, public infrastructure and property (Ghobarah 2006). The most effective way of reducing damage is to develop buildings beyond the reach of tsunami run-up. The buildings must meet the specification to increase its performance level. This performance measurement relates to the ability of the building to withstand tsunami and earthquake force and also utilized by occupant in post disaster (Ghobarah 2006). Therefore, performance level must be integrated in the planning, construction, occupation, operation and maintenance of the building (Ghobarah 2006). The urban design element of building design and construction to mitigate tsunami impact correlates to the enforcement of building regulation standards (NTHMP 2001). It might be applied to new development or existing building that are reconstructed, repaired, or rehabilitated. 


\section{CONCLUSION}

In conclusion, as the increasing of tsunami occurrence in many global major cities caused by the geodynamicsposition, urbanization and urban development, the incorporation of mitigation disaster management within city development is a must. These cities cannot delay such implementation since it will increase the cost of impact. Governments and other stakeholder can decrease this consequence by applying comprehensively structural mitigation strategies with must reflect their particular need examining the difference of social, environment, and economic aspect. The mitigation approach and policies can ensure cities serve as important role in social and economic while protecting environment for sustainability. The use of urban design's physical element for tsunami impact mitigation may meet those objectives while benefit cities and its residents. It is recommended that Infrastructure planning and design, Coastal forest, Early warning system, Emergency road network planning, Pre-tsunami evacuation planning and Building design and construction arephysical elements for tsunami impact mitigation particularly in Indonesian cities.

\section{REFERENCES}

Aksornkaoe, S. et al. (1993). Effect of sea level rise on the mangrove ecosystem in Thailand.Malaysian Journal of Tropical Geography. Vol 24, pp. 29-34.

Alesch, D., \& Arendt, L. (2012). Natural hazard mitigation policy: Implementation, organizationalchoice, and contextual dynamics. Dordrecht: Springer.

Alongi, D. M. (2008). Mangrove forests: Resilience, protection from tsunamis, and responses to global climate change. Estuarine, Coastal and Shelf Science. No. 76, pp 1-13

BAPPENAS (2005). Master Plan for the Rehabilitation and Reconstruction of the Regions and Communities of the Province of Nanggroe Aceh Darussalam and the Island of Nias, Provinceof North Sumatera. Jakarta: Badan Perencanaan Pembangunan Nasional (Bappenas) Republik Indonesia. Available at http://www.e-aceh-nias.org/index.php?id=master_plan.html.

Barbier, E.B. (2008). In the wake of tsunami: Lessons learned from the household decision to replant mangroves in Thailand. Resource and Energy Economics. No. 30, pp.229-249

Brinkman, R.M. et al. (1997). Surface wave attenuation in mangrove forests. Proceedings of 13th Australasian Coastal and Ocean Engineering Conference. No.2, pp. 941-949.

Budiarjo, A. (2006). Evacuation Shelter Building Planning for Tsunami-prone Area; a case study of Meulaboh City, Indonesia. Thesis. ITC, Eschende, The Netherland.

Chang, S.E., et al. (2006). Coastal ecosystems and tsunami protection after the December 2004 Indian Ocean tsunami. Earthquake Spectra . Vol. 22, pp.863-887.

Chatenoux, B. et al. (2007). Impacts of the 2004 Indian Ocean tsunami: analysing the potential protecting role of environmental features. Natural Hazards . Vol.40, pp.289-304

Chmutina, K., Ganor, T., \& Bosher, L. (2014). Role of urban design and planning in disaster risk reduction. Proceedings of the Institution of Civil Engineers - Urban Design and Planning,167(3), 125-135. doi:10.1680/udap.13.00011

Eisner, R. (2005). Planning for Tsunami: Reducing Future Losses Through Mitigation. Developing Tsunami-Resilient Communities, 155-162.

Farreras, S., \& Sanchez, A. (1991). The Tsunami Threat on the Mexican West Coast: A Historical Analysis and Recommendations for Hazard Mitigation. Tsunami Hazard, 301-316.

FEMA (2015). What is mitigation?. Available at https://www.fema.gov/what-mitigation

Geis, E. (2000). "By Design: The Disaster Resistant and Quality-of-Life Community." Natural Hazards Review, Vol. 1, No. 3, August, pp. 151-160.

Ghobarah, A., Saatcioglu, M., \&Nistor, I. (2006). The impact of the 26 December 2004 earthquake and tsunami on structures and infrastructure. Engineering Structures, 312-326. 
Haque, C. (2005). Mitigation of natural hazards and disasters international perspectives. Dordrecht: Springer.

ICE (1992) Coastal Structures and Breakwaters. Proceedings of the Conference coastal engineering 1992. Institution of Civil Engineers, Great Britain.

JICA (2005). The Study on the Urgent Rehabilitation and Reconstruction Support Program for AcehProvince and Affected Areas in North Sumatra. Japan International Cooperation Agency (JICA), Badan Perencanaan Pembangunan Nasional (Bappenas), and Provincial Government of Nanggroe Aceh Darussalaam, Banda Aceh.

Lunecke, M. (2015). Urban planning and tsunami impact mitigation in Chile after February 27, 2010. Nat Hazards Natural Hazards, 1591-1620.

Løvholt, F., Glimsdal, S., Harbitz, C., Zamora, N., Nadim, F., Peduzzi, P.,Smebye, H. (n.d.).(2013). Tsunami hazard and exposure on the global scale. Earth-Science Reviews, 58-73. doi:10.1016/j.earscirev.2011.10.002

MCDEM (2008). National Tsunami Signage Technical Standard for the CDEM Sector. Wellington: Ministry of Civil Defence\& Emergency Management

Mileti, D. (1999). Disasters by design: A reassessment of natural hazards in the United States. Washington, DC: Joseph Henry Press.

Mikami, T., Kinoshita, M., Matsuba, S., Watanabe, S., \&Shibayama, T. (2015). Detached Breakwaters Effects on Tsunamis around Coastal Dykes. Procedia Engineering, 422-427.

Morrissey, W. A. (2005). Tsunamis: Monitoring, Detection, and Early Warning Systems CRS Report for Congress January 24, 2005. Washington: USA Congress report.

NTHMP (2001). Designing for tsunamis seven principles for planning and designing for tsunami hazards. [Seattle, Wash.], National Tsunami Hazard Mitigation Program. Sacramento, U.S 2001.

Papathoma, M. et al. (2003). Assessing tsunami vulnerability, an example from Herakleio, Crete Natural Hazards and Earth System Sciences. No.3, pp.377-389.

Pelling, M. (2003). The vulnerability of cities: natural disasters and social resilience. London: Earthscan Publications.

Shibayama, T., Esteban, M., Nistor, I., Takagi, H., Thao, N., Matsumaru, R Ohira, K. (2013). Classification of Tsunami and Evacuation Areas. Nat Hazards Natural Hazards, 365-386.

World Bank and Badan Rehabilitasi dan RekonstruksiAceh,Aceh Province government (2008).The Impact of the Conflict, the Tsunami and Reconstruction on Poverty in Aceh:ACEH POVERTY ASSESSMENT 2008.world bank: Jakarta.

Zschau, J. (2003). Early warning systems for natural disaster reduction. Berlin: Springer. 